\title{
House ON Fire: A POLITICAL AND COLLABORATIVE ART CASE
}

\author{
Teresa Mora
}

\begin{abstract}
In this article, political art is perceived at the confluence of four trends in artistic practices today: the social turn, the reality urgency, the utopian impulse, and the collaborative practices. This confluence is articulated on the assumption that political art practices are, at least to a certain point, enhancing the transition to a collaborative model between artistic culture and social scientific and philosophical culture. Framed by this double perspective on art - political and collaborative -, this article is drawn from a major study about the House on Fire European network of festivals and theatres. The qualitative data that support this research consists of House on Fire's activity plans and programmes from 2012 to 2015 . The qualitative data was also analysed by resorting to research notes taken by the researcher in the position of spectator. This study is guided by the following aims: to explore the political agency position of House on Fire; to identify the focus of society criticism in the House on Fire's programmes; and to construct an exploratory typology of collaborative modalities between artistic culture and social-scientific and philosophical culture.
\end{abstract}

\section{Keywords}

Collaborative practices; scientific-social and philosophical action repertoires; social turn; reality urgency; utopian impulse

\section{Resumo}

Neste artigo, a arte política é pensada na confluência de quatro tendências das práticas artísticas na atualidade: a viragem social, a urgência da realidade, o impulso utópico, e as práticas colaborativas. Tal confluência é articulada com o pressuposto de que as práticas de arte política, assim configuradas, estão, pelo menos em parte, a potenciar a transição para um modelo colaborativo entre cultura artística e cultura científico-social e filosófica. Perspetivada a arte nesta dupla vertente - política e colaborativa -, o artigo focaliza-se numa investigação em progresso sobre a rede de teatros e festivais europeus House on Fire. O material que apoia a investigação é relativo ao período 2012-2015 da ação da rede, sendo composto por planos de atividade e programas. A análise do material qualitativo é ainda suportada por anotações feitas pela investigadora na qualidade de espetadora-investigadora. Os objetivos que enquadram o estudo são os seguintes: estabelecer o estatuto de agente de arte política da House on Fire; identificar, na sua programação, os focos temáticos de crítica societal; e elaborar uma tipologia exploratória das várias modalidades de colaboração entre cultura artística e cultura científico-social e filosófica.

\section{Palavras-chave}

Impulso utópico; práticas colaborativas; repertórios de ação científicosocial e filosófica; urgência da realidade; viragem social 


\section{POLITICAL AND COLLABORATIVE ART: SIGNS AND SUPPOSITIONS}

Since the late 1990s, artistic practices in a variety of fields, ranging from visual arts to performative arts, have taken on interdisciplinary or transdisciplinary formats that appear to display a tendency towards the blurring of the traditional institutional divide between artistic culture, on the one hand, and scientific-social and philosophical culture, on the other. Examples of this are to be found worldwide, including in Portugal and in Europe particularly.

The Reina Sofia Museum has pursued an editorial line characterised by social responsibility and political reflection since the first issue (Spring-Summer 2010) of the journal Carta, which has the meaningful subtitle of Revista de pensamento y debate del Museo Nacional Centro de Arte Reina Sofía [Journal of thought and debate of the Reina Sofia National Museum Art Centre]. The "Next Future" - Gulbenkian Programme of Contemporary Culture - 2009 to 2015 - had, under the curatorship of António Pinto Ribeiro, two avenues of work: "theoretical research and production" (in collaboration with research centres) and "artistic production and programming"' (in a variety of fields, such as theatre, music, cinema and photography). There were various dissemination outlets, such as the publication of Grandes Lições (2013), which included work by economists, historians, humanists, poets, sociologists and artists.

In Europe and the United States, of the various institutional exhibitions of visual arts that from 2011 to $2013^{2}$ established a dialogue between art and utopia, Sin realidad no hay utopía, shown first in Seville (2011) and later in San Francisco (2013), was based on the "critical reflection of the philosopher Jean Baudrillard and the German literature professor Andreas Huyssen" (see Cardoso \& Lobo, 2013, p. 311). This exhibition was organised into two sections, one on "the Lie" of politicians and the other on four "collapses": of communism, capitalism, democracy and geopolitics.

Many other examples could be given to show the "new institutional experiences", including the dialogue between social movements, universities and research centres, as is the case of the Universidad Nómada networked with the CENDEAC (Centro de Documentación y Estudios Avanzados de Arte Contemporáneo) [Centre for Documentation and Advanced Studies on Contemporary Art] in Murcia (Rodríguez, 2012, p. 41). By looking at the abovementioned cases I seek to examine the political relevance of the role that artistic-cultural agents (curators, directors, artists) increasingly seem to be playing within the context of a critique of a model of society, which has progressively become the one we have been living in since the beginning of the 21 st century, particularly in Europe.

By political art I mean "art that further questions society's mode of organisation in terms of its structures of power and domination" (Mora, 2016, p. 6). In line with André Carmo, who draws closely on Boyan Manchev, I would agree that " by playing out in a

\footnotetext{
' Retrieved from http://www.proximofuturo.gulbenkian.pt/proximo-futuro

${ }^{2}$ Without Reality There Is No Utopia, Yerba Buena Center for the Arts de S. Francisco (EUA), 25 Feb. to 2 June 2013; Sin realidad no hay utopia, Centro Andaluz de arte Contemporânea, Sevilha, 2011; Utopia, Hoxton Art Projects Gallery, London, Jan. to March . 2012; The Spirit of Utopia, White Chapel Gallery, London, July to Sept. 2013; Utopien in Kleinen Masstab, Trienal de Escultura em Miniatura de Feelbach, Germany, June to a Sept. 2013.
} 
constellation of artistic practices, political art is precisely so since it has the necessary potential to stand up to the regimes of sovereignty, domination and oppression" (Carmo, 2014 , p. 120). Nowadays, one can make the assumption that the organisation mode of society which is closest to us, and is commonly referred to as the Euro-American model, may be regarded as comprising, among others, the following features: "the voraciousness of capitalism; the establishment of a neoliberal policy; the fragility of democracy; the breakdown of the social contract; the dismantling of the Social State" (Mora, 2016, p. 5); the "reconfiguring of the State into a commodification mechanism" (Bernardo, 2015, p. 14); "the rise of social fascism" (Santos, 2002, 2006, 2007); and the ecological threat.

It should also be underlined that, from an analytical point of view, the political importance which artistic-cultural agents may nowadays take on can be observed at two levels:

by the reflection they generate on the aforementioned model of society; (...) by seeking, through their artistic endeavour, to give rise to other possibilities of mitigating social problems, and other ways of life and ways of living together, calling ,more or less openly, for an other life - one of fairness and social well-being (Mora, 2016, p. 5)

It is also my assumption that it is the actual development of political art practices that seems to be, at least to a certain extent, furthering the transition towards a collaborative model between artistic culture, and scientific-social and philosophical culture. Lastly, and in a broader sense, the current political potential of art should, in my view, be perceived at the confluence of four trends which, since the late 2oth century, have emerged in artistic practices: "the social turn; reality urgency; the utopian impulse; and collaborative practices (Mora, 2016, p. 5).

When using the expression political "potential" of art, I seek to invoke both the contrast and the opposing relationship between the usual notion of potere (power), i.e., "power over", and the notion of potentia (potency), as understood by Espinosa and developed by Negri. I am referring to the "power to" in the sense of carrying out an action, which means, for example, that I "realise the human potential to swim if I actually learn to swim" (Keucheyan, 2013, p. 125). As regards the opposition between the two powers, the usual sense of power "consists in separating individuals from their potential", whereas "to realise a potential consists in freeing oneself from the constraints imposed by power" (Keucheyan, 2013, p. 125).

\section{POLItical ART AND \#4}

The social turn as employed by Claire Bishop $(2006,2012)$ elicits quite a number of concepts: “'new genre public art' (Lacy, 1995); 'esthétique relationnel' (Bourriaud, 1998); 'conversational art' (Bhabha, 1998); 'dialogue-based public art' (Finkelpearl, 2000); 'dialogical art' (Kester, 2005); 'participatory art' (Bishop, 2006); 'collaborative art' (Kester, 2011), etc." (Mora, 2016, p. 5). Although they point at a variety of conflicting artistic 
practices and discursive roots (Malzacher, 2015, p. 17), these concepts do have "common ground in that art has a marked tendency to take on, in various shapes and forms, its social (or relational) value" (Mora, 2016, p. 5). In that sense, all these concepts, deriving mostly from the artistic field, reveal, in their own particular way, the same tendency for the arts to move towards the relational (or social) logic (traditionally) underlying the social sciences, namely the identity relationship self-other (in anthropology), the intra or intergroup relationships (in social psychology), or the social relationships (in sociology).

The reality urgency or the reality trend is advocated by the theatre movement "Theatre der Zeit", which was created in 2002 as a form of documentary theatre featuring non-artists staged by the group Rimini Protokoll. This trend is particularly reflected in the "artistic portrayal of the public debate on the world we live in and its specific societal problems", which highlights the "proximity between the value of the knowledge derived from artistic practices and knowledge about the world today produced in the course of scientific-social practices" (Mora, 2016, p. 6).

The critical thought underpinning political art "lies not only in the attitude of rejection brought about by a particular artistic practice but also in the alternative openness to other possible ways of being/living" (Mora, 2016, p. 6). It is, thus, a trend towards developing artistic practices that are regarded by those who undertake them as alternative practices in two different ways: by expressing themselves in a language of emancipation from exploitation, domination, stigmatisation and peripheralisation, on the one hand, and by, more or less explicitly, calling for an other life, one of fairness and social well-being. Also in this respect, meaning the trend towards active political engagement, one is not far from some of the practices typical of the social sciences and political philosophy, such as is the case of those associated to the Marxist tradition or those expressing contemporary critical thought that have been re-emerging since the late 1990s (Keucheyan, 2013; Unipop, 2014).

This study is concerned with further pursuing research on "artistic practices in which the movement to deny what is established opens itself up to (...) an 'exercise' to explore the 'lateral possibilities' of the reality which Ruyer defined as being typical of the 'utopian mode' of thought" (Mora, 2016, p. 6). This game of "overflowing the boundaries of the known world" (Mora, 2009, p. 1) drives one to consider the element of "utopia" when conceptualising political art. In my view, political art generates actions meant to deny/criticise the world we live in, which, with varying degrees of intensity and alternative potential, contain in them an element of rupture and openness that I call utopian impulse.

The largely relational (or social) nature of collaborative art can be perceived in different shapes and forms: in the plural engagement of artists with social researchers, activists, associations, local authorities, etc. working in co-authorship or establishing horizontality relationships (Hand, 2010, pp. 14-15); in projects enabling the direct interaction between individuals, groups, residents, communities, or other groups of individuals; in the very diverse levels of operation, be they symbolic or territorial - the public space, on the streets, in neighbourhoods, schools, prisons, shelters, hospitals, therapeutic communities, etc., - employing a variety of modes of agency, such as awareness raising, 
participation, citizenship, sustainability; in its quest to improve the real (material and/or symbolic) circumstances of people and populations; in operating in political, economic, cultural contexts marked by trangression, segregration, exclusion, ghettoisation, stigmatisation, discrimination, peripheralisation, deprivation, degradation...

There are a few examples that stand out when it comes to the diversity, in terms of participants and objectives, of collaborative practices. The project "A festa acabou" [The party has ended] (2006-2009), which was carried out in the Quinta da Vitória neighbourhood in Loures (in the Lisbon metropolitan area) by a team of visual artists, curators, anthropologists and residents (Borges, 2012), was a local intervention and participation project. Its purpose was to "create an image of the neighbourhood produced by the residents themselves which could act as a counterpoint to the images associated to crime, violence and poverty that were broadcast to the public" (Borges, 2012, p. 200). The "Wetraders - Troca-se Crise por Cidade" project [We-traders - Swapping Crisis for City], promoted by the Goethe-Institut since 2013 and thought out by the artist and designer Rose Epple and the architect Angelika Fitz, is a knowledge and dissemination network that connects the initiatives by artists, designers researchers, in five European cities, Lisbon, Madrid, Toulouse, Turin and Berlin. The collaborative projects developed in these cities pursue a wide range of objectives and are undertaken by autonomous groups. Lisbon, for example, has five very distinct projects: "Cozinha Popular da Mouraria" [Mouraria Folk Cooking], "Agulha num Palheiro" [Needle in a Haystack], "O Espelho" [The Mirror], "A Linha" [The Line] and "BIP/ZIP".

It is this movement towards the institutionalisation of interdisciplinary collaborations with the purpose of setting up collective action groups driven by a variety of social (or relational) projects that also seems to be becoming a trend in the specific field of political art.

\section{RESEARCH FEATURES}

The House on Fire ${ }^{3}$ network of ten European theatres and festivals, which, in Portugal, was founded by the Maria Matos - Teatro Municipal de Lisboa [Maria Matos Lisbon Municipal Theatre] in 2011, lends itself well to the purpose of researching the tendency towards the blurring of the boundaries between artistic practices and scientificsocial and philosophical knowledge within the context of political art. In its discursive practice, the Maria Matos (MM) - a founding member and coordinator of the networkassumes its role as an agent of political art and in its programming adopts a recurring and consistent role of promoting the model of collaboration between artistic culture and scientific-social and philosophical culture.

\footnotetext{
${ }_{3}^{3}$ Comprising : Maria Matos Teatro Municipal/EGEAC - Lisbon (Portugal) - coordinator; Kaaitheater - Brussels (Belgium ), Bergen Internasjonale Teater - Bergen (Norway); ARCJA Theatre - Prague (Czech Republic); Théâtre Garonne - Toulouse (France); Frascati - Amsterdam (Holland); MALTA Festival - Poznan (Poland); BRUT - Vienna (Austria); HAU/Hebbel Theater - Berlin (Germany); LIFT/London International Festival of Theatre - London (Great Britain); supported by the Culture Programme of the European Union from 2012 to 2017.
} 
The empirical data which I have examined in my research on House on Fire pertains to the activities carried out from 2012 to 2015 and comprise the following: their website ${ }^{4}$, their programming (June 2012 - December 2014), the MM artistic and cultural proposal (October 2014 -September 2018), publicity material for the MM programming and the production programmes.

The findings presented herein are based on this material which concerns the discursive pole of House on Fire, materialised by MM as a founding and coordinating theatre of the network. In this stage of the research, the other artistic companies comprising the network have not been considered and are regarded as discursive nodes which will, at a later stage, be selectively examined, namely by looking at their own particular means of dissemination, such as websites and artists' interviews in the press. In addition and complementarily, the findings also derive from the notes taken on field trips I have made to the MM since July 2013. At first as a mere spectator and later as a participating observer, which enabled me to re-view how the discursive underpinnings of the programming that I had previously examined materialised into artistic practices, and then, in my capacity as a spectator-researcher, to gradually reorganise them.

It is at the intersection of these two facets - the political and the collaborative- that the abovementioned material is studied. As far as the political facet is concerned, the status of political art agent is established as a distinguishing feature of the House on Fire network, and themes focusing on a critique of society are identified for the 2012-15 programming. As for the collaborative facet, one explores "action repertoires" (Tilly, 1986) or stocks of means of action - themes, issues, authors, theories or concepts, works - deriving from the scientific and philosophical discursive regimes. It is based on the latter facet that one seeks to define the various modalities of collaboration between artistic culture and scientific-social-philosophical culture occurring in House on Fire in in their 2012-2015 programming.

\section{HOUSE ON FIRE AND POLITICAL ART}

The status of political art agent accorded to House on Fire is perceivable from the outset in "its critically charged name" (Mora, 2016, p. 6): Fire "means urgency"; House "stands for the sustainability we are seeking". This commitment is set out in the document detailing its action: "the co-organisers of House on Fire seek to internationalise and share the strong creative impulses of the new paradigm of social responsibility and political activism that is emerging in the performative arts and in the arts in general" 5 . The "knowledge value of artistic practice in the public debate" (Mora, 2016, p. 7) on today's society is unequivocally stated:

in recent years, there has been a radical change in the performing arts and in the arts in general. Artists, curators, theatre directors and cultural agents

\footnotetext{
${ }^{4}$ Retrieved from http://www.houseonfire.eu/home

${ }^{5}$ House on Fire: detailed description of the action, undated. (photocopied, 11 pgs.).
} 
have begun to claim their place in the public debate on social, environmental and political issues, maintaining that artists have an active role to play in society and that artistic creation provides a particular and valid source of knowledge and experience ${ }^{6}$.

Lastly, "the status of 'public space' (in the Habermasian sense of the term) is accorded to the theatre" (Mora, 2016, p. 7):

we acknowledge that the Maria Matos Theatre has taken on a responsibility to stimulate public debate. We see the theatre as a space for reflection on the state of the world and we believe that artistic creation and critical thought can meet and become a powerful weapon against indifference and the lack of civic engagement. (Depputer quoted in Mora, 2016, p, 7):

The critical output of the House on Fire network is undertaken in terms of programming by the $\mathrm{MM}$ at a transnational level encompassing the ten participating countries. Thus, in the MM Artistic and Cultural Proposal (2014) it is stated:

with the creation of (...) House on Fire (...) the themes comprising the programme (...) are developed in collaboration with the network partners, involving co-commissioning of works of art, shared organisation of conferences and lectures, contact and information sharing and discussion of ideas and projects. (Deputter, 2014)

The network's political potential is also associated to the organisational openness towards both knowledge and agents from other cultures besides the performative arts, such as scientific-philosophical culture, civic organisations/associations and the common citizen. This blurring of boundaries which is typical of a collaborative cultural model is clearly noticeable in the various features that are set out in the "MM Artistic and Cultural Proposal" (2014) as arguments for the critical activity to be developed. One of these features is the "furthering of contacts between radically different areas of knowledge", spurred on by a logic of horizontality, in which "academic analysis" and "philosophical discourse" have their place alongside "artistic approaches", "participation by civic associations" and actual "daily life experiences" (Deputter, 2014). Another of the features is a focus on "Debate \& Thought" programmes in a "sustained effort to bring together artists, thinkers and spectators to discuss important current issues, such as 'Governance', 'Time', 'Public/Private', 'Manifesto'” (Deputter, 2014). One final feature worth mentioning is the collaboration with agents from outside the network as is the case of "independent organisations such as Unipop, Baldio, the London organisation Julie's Bicycle, the German cultural initiative FuturZwei and the Cities in Transition movement" (Deputter, 2014). The different network partners also have close contacts with a variety of European academic institutions, such as Von Humbolt University (Berlin), the New Economics Foundation (London), the Institute for European Studios (Brussels), the University of Amsterdam and the Institut fur Theater, Film und Medienwissenschaft (Vienna).

\footnotetext{
${ }^{6}$ House on Fire: detailed description of the action, undated. (photocopied, 11 pgs.).
} 
The House on Fire network develops its critical activity through "Debate \& Thought" programmes at a transnational scale (involving the countries in the network) that are built around three types of activities: co-production of performative arts creations, both on a small and large scale, involving either experienced or emerging artists and comprising a variety of performative formats (theatre, dance, performance, happening, etc.); co-organisation of multidisciplinary cultural events; online publication of copy-books (in each country's original language and in English) about the network's activities (which include interviews with artists, critical analyses, descriptions of work processes and methodological proposals) ${ }^{7}$.

From 2012 to 2015 the House on Fire network developed six thematic programmes: 1- Art \& Politics; 2- Biopolitics Gender Politics and Transhumanism; 3- Cultural Diversity at a Crossroads; 4- Government, Conflict and War; 5- The Individual and the Common; 6- The Politics of Economy. Four of these programmes focus on current themes which address various problematic issues facing society (the economy, culture, gender, etc.); the "Government, Conflict and War" programme, on the other hand, pertains to the First World War and was carried out at the Lift Festival in London in 2014 to mark the 1ooth anniversary of the conflict; "The Individual and the Common" programme stands out from the others in that it focuses on what has always been a central issue in social sciences, particularly in the history of sociology, but which since the late 1990s has become the renewed subject of debate. It is a debate which encompasses "various attempts to overcome the opposition individual/collective". It focuses particularly on "the discussion of new names for a collective political subject" such as, for instance, "the plebs" in Martin Breaugh, the concept of multitude in Toni Negri and Michael Hardt's writings, or in Paolo Virno's. It focuses equally on "new ways of looking at the form of community" as is the case of Jean-Luc Nancy's "being-in-common", which is onthologically driven to "take on the in - common dimension of being itself" (Dias \& Neves, 2010, pp. 377-378).

The critical nature of the House on Fire programming is clearly visible in the titles of several of the events that comprise each of the six thematic programmes ${ }^{8}$ and regularly comes through in the texts that present or publicise the events ${ }^{9}$. To illustrate this point, three series of events will be mentioned.

"Phantasm and Politics", one of the nine series of events comprising the Programme "Art \& Politics", consisted of film screenings, conferences and ten debates that were held at the Brut Wien (Austria) throughout 2014 on a monthly basis. "Session \#7" of this series involved the presentation of the "Truth is Concrete" project over a period of

\footnotetext{
7 House on Fire: detailed description of the action, undated (photocopied, 11 pgs). See the first publication of House on Fire: Malzacher, F. (Ed.) (2015). Not just a mirror. Looking for the political theatre of today - Performing Urgency \#1. Santo Tirso: House on Fire.

${ }^{8}$ In the 2012-2015 programming period of the House of Fire network, 29 series of events were held covering the various thematic programmes: 1- Art \& Politics (9 series); 2- Biopolitics Gender Politics and Transhumanism (3 series); 3- Cultural Diversity at a Crossroads (4 series); 4- Government, Conflict and War (3 series); 5 - The Individual and the Common (5 series); 6- The Politics of Economy (5 series).

9 See the programmes printed bimonthly by the Maria Matos - Teatro Municipal de Lisboa, or visit the House on Fire website: http://www.houseonfire.eu/home
} 
seven days at the Steirischer Herbst Festival in September 2012 in Graz, Austria with the motto "art should be a tool with which to shape the world rather than just reflect it" 10 . A book with the same title (Truth is concrete), edited by one of the curators of the event, the playwright Florian Malzacher (2015), was then published with the meaningful subtitle Handbook for Artistic Strategies in Real Politics. This is not an isolated case of art turning towards reality but rather the expression of the programming philosophy of the new Reality Trend, developed by Rimini Protokoll with whom House on Fire has close ties".

Within the scope of the Biopolitics Gender Politics and Transhumanism programme, a series of events entitled Straight White Men - A Festival about Privilege was held in 2014 and 2015 in three of the network's ten European theatres. It comprised performances, debates, music, theatre, dance and films that all built on the starting point that was the play Straight White Men staged within the context of the series by the American theatre company Young Jean Lee's Theater. The setting is a living room somewhere in a US suburb where "a father and his three middle-aged sons must tackle a seemingly simple question: What can a privileged, heterosexual, white man do to fight against the continued existence of an unjust system?"12.

From September 2013 to April 2014, the series There's no such thing as society was held at the MM as part of "The Individual and the Common" programme. By updating Margaret Thatcher's famous 1980 s neo-liberal quote to the $21^{\text {st }}$ century, this series of events rekindles the debate on the relationship between the individual and the collective in "four stages" that question the premises of the French Revolution -solidarity (December 2013), fraternity (March 2014) and liberty (April 2014) ${ }^{13}$. To close the first stage (introduction) of There's no such thing as society, the German social psychologist Harald Welzer held a workshop (28 September 2013) to present the FuturZwei (Future Perfect) project, which now has an eponymous website. In contrast with the TINA - "There is no alternative" mega-narrative constructed by Thatcher and updated to the early 21st century, FuturZwei seeks to place the narrative "everybody can do something" very much in the foreground, employing the utopian elements of rupture and openness in its discursive action:

we want to ensure visibility and credibility for stories that rebut the story that western capitalist societies tell about themselves. Our utopia is to become an agent for the development of a social movement that does not yet know it exists's.

Having attended Harald Welzer's workshop, I was able to summarise the reasoning underlying his project in three topics: firstly, to counter the common cause-effect relationship between the argument that "the system is complex" and the argument that as a

\footnotetext{
${ }^{10}$ Retrieved from http://www.houseonfire.eu/home

"House on Fire: detailed description of the action, undated. (photocopied, 11 pgs.).

${ }^{12}$ Retrieved from In http://www.houseonfir.eu/

${ }^{13}$ See Programa Maria Matos Teatro Municipal, September_October 2013, p. 9.

14 Programa Maria Matos Teatro Municipal, September-October, 2013, p. 19.
} 
result " it is very complicated for any one of us to change it ..."; secondly, to change the relationship between theory and practice, both by reversing this order and by mapping out an ethic normalising the contradiction between action and thought; thirdly, to replace the negative mega-narrative quantifying visions and forecasts of catastrophe and scarcity, underpinned by the evolutionary thought of a better future, by a set of "counter-narratives" comprising positive, qualitative and cumulative alternative practices to the "consumer and throw-away society". The purpose of these alternative practices is to show "stories about a possible future" that act as "first movers" (which we can emulate if we want to) as well as being "an incentive for the re-politicization of the collective sphere of life".

\section{HOUSE ON FIRE AND COLLABORATIVE ART}

The use of "action repertoires" or stocks of means of action (Tilly, 1986) - in this case, themes, issues, authors, theories or concepts, and works deriving from the scientific and philosophical discursive regimes - is visible in the House on Fire programming in various modalities, which I have tentatively grouped into five categories.

Conferences/lectures with keynote speakers from philosophy and other scientific fields (particularly human and social sciences) are a regular and transversal feature of the various "Debate \& Thought" programmes organised by House on Fire. Within the context of "The Politics of Economy" thematic programme, for example, the series "Transição"15 [Transition] was held at the Teatro Maria Matos from April to July 2013, with the issue of sustainability being addressed in succession by six speakers ${ }^{16}$, covering natural resources, work, food, the economy, the environment and life style.

The presence of certain thinkers, from the fields of science and philosophy, acting as catalysts for series of events is a second modality, which is exceptional, in contrast with the regularity of the first, abovementioned, one. This was the case of the series "Gender trouble - performance, performatividade e política de género" [Gender trouble - performance, performativity and politics of gender], which also took place at Teatro Maria Matos, from May to July 2015, to mark the 25th anniversary of the publication of the book Gender Trouble. Feminism and the subversion of identity by Judith Butler, who was also a speaker at the conference on $2^{\text {nd }}$ June ${ }^{17}$.

\footnotetext{
${ }^{15}$ The Transition movement, also known as the Transition Network appeared in 2005-2006 when Rob Hopkins and Naresh Giangrande founded Transition Town Totnes (Totnes is a town in England). The Transition Network currently has more than one thousand initiatives registered on the five continents. Retrieved from https://transitionnetwork.org/

${ }^{16}$ Peter Tom Jones (engineer), "The transition to a low-carbon circular economy", $3^{\text {rd }}$ April, 2013; Anselm Jappe (philosopher), "Après la fin du travail: vers une humanité superflue?"["After the end of work, towards a superfluous humanity?"] $23^{\text {rd }}$ April, 2013; Carolyn Steel (architect), "Sitopia - the transformative power of food", 21 ${ }^{\text {st }}$ May. 2013; Paulo Magalhães (lawyer), "O desafio de nos organizarmos como vizinhos globais" ["The challenge of getting organized as global neighbours"], $5^{\text {th }}$ June, 2013; Tim Jackson (economist), "Prosperity and sustainability in a green economy", $24^{\text {th }}$ June 2013; Viriato Soromenho Marques (philosopher), "Riscos e oportunidades numa era de transição para a sustentabilidade" ["Risks and Opportunities in an Era of Transition towards Sustainability]", 16 $6^{\text {th }}$ July, 2013.

${ }^{17}$ More recently, the series "As três ecologias" [The Three Ecologies] was held in March and April 2016 at the MM in Lisbon, and the catalyst for it was the eponymous work, Les Trois écologies (1989) by Félix Guattari, from which it takes up the idea of interconnecting the three dimensions of ecology, personal, social and environmental, as set forth by the French philosopher.
} 
A third modality is based on the centrality of certain authors/works that serve as a basis for devising artistic projects. The video-art work Dancing Gender Trouble by the Spanish team of Helena Cabello \& Ana Carceller is an example of this. It was featured in the series of events which had Judith Butler as a catalyst and consisted in a performance giving physical form to the contents of the iconic book by participants who had no previous dance experience, with words from Gender Trouble being uttered instead of music being played.

The collaboration of academics in devising artistic projects is a fourth modality which clearly reflects a culture of overcoming the traditional institutional divide between scientific work and artistic work. The play Some use for your broken clay pots by Christophe Meierhans is an example of this. It was included in the series "There's no such thing as society", held from September 2013 to April 2014 at the Maria Matos, as part of "The Individual and the Common" programme. With the aid of political science and constitutional law scholars, Meierhans (2014) creates a new constitution, which is the cornerstone of the play and is also published as a multilingual book (French, English, Dutch and German).

The artist explains that "the play is inspired by the practice of ostracism in the ancient city of Athens, which every year allowed citizens to ban from the city a political leader whom they regarded as being harmful for the government of the city" (Teatro Maria Matos, 2016). The "names of the people to be expelled" were "supposedly engraved either on oyster shells (from the Greek: ostreon) or on pieces of broken clay (ostraka)" (Teatro Maris Matos, 2016), with the latter explaining the choice for the title: Some use for your broken clay pots.

Some use for your broken clay pots also has some of the features of the lectureperformance, the fifth modality, which I view as a hybridisation of artistic practice with academic practice. The Meierhans play is a (press) conference delivered in direct speech, with the aid of an overhead projector, to an audience that is "cast in the role of electors" who have "to imagine what kind of citizens and what kind of society" the alternative constitution presented to them "would be able to produce" (Teatro Maria Matos, 2016).

Lecture for everyone, by the artist Sarah Vanhee is another example of a lectureperformance, which took place within the same series ("There's no such thing as society") in Lisbon, from $7^{\text {th }}$ to $14^{\text {th }}$ December 2013. It is in a wide range of organisational and institutional settings (such as the Gulbenkian choir, the Gil Foundation, the Goethe Institut, the Universidade Nova - School of Business and Economics, the Saint Cecilia Music Academy, Vodafone, the Lisbon City Hall, etc.) that "the artist intrudes into meetings or assemblies" (Mora, 2016, p. 8): a Bach Christmas Oratorio rehearsal, a team meeting, a teachers' meeting to discuss students' grades, a PhD student seminar, a staff meeting to plan the company Christmas dinner, a clinical session by a medical service, etc. Immediately after having given a fifteen-minute lecture, the text of which does not change from one setting to the other and consists of a "hybrid of stories and political reflections and performative momentum" (Vanhee quoted in Mora, 2016, p. 8), the artist leaves the meeting without communicating with anyone present. One can view this 
lecture - performance as an "illustration of a utopian moment: a fragment of time and space through which the artist attempts to get the "openness to the lateral possibilities'" of the purpose of the meeting or "of its agenda to emerge" (Mora, 2016, p. 8).

For an archaeology of lecture performances, one has to consider Robert Morris, John Cage or Joseph Beuys as the first references. In 1964, Robert Morris performed 21.3, in which he took to the stage as if he were a professor, wearing formal clothing in an equally formal setting with a podium, a microphone, a jar of water and a glass, giving a lecture on the introduction of the well-known Erwin Panofsky essay on iconography and iconology called Studies in Iconology written in 1939 (Blasco, 2013, pp. 13-14). Oral and direct discourse, rather than a predominantly bodily performance, and its staging with resort to material supports (in this case, those most traditionally associated with a classic academic context, but they may just as well be audio-visuals, PowerPoint or other media) are two of the features of lecture-performances, according to Olveira. (see Olveira, 2014, pp. 7-10). These features allow one to perceive lecture-performances as a practice that is on the boundaries or as a practice between artists and academics, which, in turn, also points to the indistinctive audiences it is addressed to since it attracts both academic and non-academic audiences. In this regard, another recurring feature of the lecture-performance is the interaction and the conversation with the audience and their participation. In addition to these and other features (see Olveira, 2014, p. 10), what should be underlined above all is that the lecture-performance modality becomes political when it is a critical action practice which is undertaken through the deconstruction and/or subversion of the hegemonic codes, as is the case of classic 21.3 by Morris.

\section{FinAL REMARKS}

Regarding the 2012-2015 House on Fire programming, through the research conducted I was able identify other instances of the five modalities of collaboration between artistic culture and scientific-social and philosophical culture which could be discussed herein. However, that would always have to be on the understanding that only a continued, expanded and in-depth study of the cases that illustrate them will, in future, enable one to determine the power of House of Fire to destabilise the traditional institutional divide between artistic culture and scientific-philosophical culture.

The political potential of House on Fire was examined at the confluence of what were considered to be the four trends that have emerged in current artistic practices: the "social turn", the reality urgency, the utopian impulse and the collaborative practices. One has, nonetheless, to accept that a more comprehensive explanation of the role of artistic agents in the development of political art requires one to consider the importance of public policies, at various levels of power (municipal, national, supranational) due to the role they play in (re)configuring artistic projects as objects, tools or outcomes of their action. This notwithstanding, the research conducted enabled one to ascertain that House on Fire is a solid and consistent case of political art, with the MM, as its discursive pole, having been afforded significant institutional importance. 
Finally, the network structure together with the European scope of the programming coproduced and presented by the ten House on Fire theatres and festivals have resituated the MM - Teatro Municipal de Lisboa on an inter-national and European level, which does seem to beg the following question: to what extent can the European artisticcultural networks (with House on Fire being just one such case) imprint an alternative (in the political sense of the word) potential on the cultural context of Portuguese society?

\section{Traduzido por João Paulo Silva}

\section{BibLIOGRAPHIC REFERENCES}

Bernardo, L. (Ed.) (2015). Correntes invisíveis. Neoloberalimo no século XXI. s/l: Deriva Editores.

Bhabha, H. (1998). Conversational art. In M. J. Jacob \& M. Brenson (Eds.), Conversations at the Castle: Changing Audiences and Contemporary Art (pp. 38-47). Cambridge, Mass and London: MIT Press.

Bishop, C. (2006). The social turn: colaboration and its discontents. ARTFORUM, february, 178-183.

Bishop, C. (2012). Artificial hells: participatory art and the politics of spectatorship. London \& New York: Verso.

Blasco, S. (2013). Mantener las formas. La academia en y desde las prácticas artísticas. In S. Blasco (Ed.), Investigación artística y universidade: materiales para un debate (pp. 11-41). Madrid: Ediciones Asimétricas.

Bloch, E. (1995). The principle of hope. Cambridge: Mass/ MIT Press.

Borges, Sofia (2012). Quando o artista decide abrir a porta do seu atelier e começa a olhar à sua volta. Revista Crítica de Ciências Sociais, 99, 185-202. doi: 104000/rccs.5157

Bourriaud, N. (1998). L'esthétique relationnelle. Dijon: Les Presses du réel.

Cardoso, I. L. \& Lobo, P. (2013). O paraíso é aqui e agora: busca, construção e perda da utopia. Notas sobre política, arte e globalização. In M. Acciaiuoli; A. D. Rodrigues; M.J. Castro; P. André \& P. S. Rodrigues (Eds.), Arte Q Utopia (pp. 309-322). Várzea da Rainha: Várzea da Rainha Impressores, S.A.

Carmo, A. (2014). Cidade e cidadania (através da Arte). O Teatro do Oprimido na região metropolitana de Lisboa. Doctoral thesis, Universidade of Lisbon / Institute of Geography and Spatial Planning, Portugal (policopiado).

Deputter, M. (2014). Maria Matos Teatro Municipal Outubro 2014 - Setembro 2018 - Proposta artísticocultural, 16 junho.

Dias, B. P. \& Neves, J. (Ed.) (2010). A política dos muitos. Povo, classes e multidão. Lisbon: Tinta da Chna.

Finkelpearl, T. (2000). Dialogues in puin dialogical relation public art. Massachusetts/London: The MIT Press.

Guattari, F. (1989). Les trois écologies. Paris: Éditions Galilée.

Hand, B. (2010). A struggle at the roots of the mind: service and solidarity in dialogical relational and collaborative perspectives within contemporary art. In IMMA, What is participatory and relational art? (pp. 8-17). Dublin: Irish Museum of Modern Art - IMMA.

Kester, G. (2005). Conversation pieces: The role of dialogue in socially-engaged art. In Z. Kucor \& S. Leung (Eds.), Theory in Contemporary art since 1985 (pp. 76-100). Oxford: Blackwell. 
Kester, G. (2011). The one contemporary collaborative art and the many in a global context. Durham, N.C.: Duke University Press.

Keucheyan, R. (2013). Hémisphère gauche. Une cartographie des nouvelles pensées critiques. Paris: Éditions La Découverte.

Lacy, S. (1995). Mapping the terrain: New genre public art. Seattle: Bay Press.

Malzacher, F. (2015). Putting the urinal back in the Restroom - The symbolic and the direct power of art and activism. In F. Malzacher (Ed.), Truth is Concrete - a Handbook for Artistic Strategies in Real Politics (pp. 12-25). Berlin: Steirischer Herbst /Strenberg Press.

Malzacher, F. (Ed.) (2015). Not just a mirror. Looking for the political theatre of today - Performing Urgency \#1. Santo Tirso: House on Fire.

Meierhans, C. (2014). Some use for your broken clay pots. Gent: Mer.

Mora, T. (2016). The individual and the common: arte política e crítica social. In Portugal: Território de territórios. Atas do IX Congresso Português de Sociologia. Lisbon: Associação Portuguesa de Sociologia.

Mora, T. (2009). Viagem, utopia e insularidade: narrativas fundadoras da ciência e da sociedade moderna. Lisbon: Fundação Calouste Gulbenkian/ Fundação para a Ciência e Tecnologia.

Olveira, M. (Ed.) (2014). Conferencia performativa. Nuevos formatos, lugares, prácticas y comportamentos artísticos. Castilla y Léon/Madrid: MUSAC/ This Side Up.

Ribeiro, A. P. (Ed.) (2013). Grandes Lições. vol. 1, vol. 2. Lisbon: Fundação Calouste Gulbenkian.

Rodríguez, A. (2012). Viragem pedagógica, capitalismo cognitivo, nova institucionalidade. Imprópria, 1, 39-42.

Ruyer, R. (1950). L'utopie et les utopies. Paris: PUF.

Teatro Maria Matos (2016). Some use for your broken clay pots - Lisboa, 5,7 e 8 de março. Folha de Sala.

Tilly, C. (1986). La France conteste. De 1600 à nous jours. Paris: Fayard.

Unipop (Ed.) (2014). Pensamento crítico contemporâneo. Lisbon: Edições 70.

\section{BIOGRAPHICAL NOTE}

Teresa Mora is researcher at the Interdisciplinary Centre of Social Sciences (CICSUMinho) and assistant professor of Sociology at the University of Minho. PhD in sociology at University of Minho (2007). She has been doing research on the similarities between social theory and social utopia, which has resulted, amongst others, in the following publications:

- Mora, T. (2013). Classics of Sociology and Modern Social Utopias: Displacing Knowledge Boundaries. In J. Bastos da Silva (Ed.), The Epistemology of Utopia: Rhetoric, Theory and Imagination (pp. 65-79). Newcastle upon Tyne: Cambridge Scholars Publishing. ISBN (10): 1-4438-4625-2, ISBN (13): 978-1-4438-4625-7 
- Mora, T. (2009). Viagem, utopia e insularidade: narrativas fundadoras da ciência e da sociedade moderna. Lisboa: Fundação Calouste Gulbenkian/ Fundação para a Ciência e Tecnologia. ISBN: 978-972-31-1272-6

Her current research interests are centred on political and social engaged art, with a particular focus on collaborative practices between artists and social scientists.

E-mail: tmora@ics.uminho.pt

Centro Interdisciplinar de Ciências Sociais (CICS-UMinho) - Instituto de Ciências Sociais - Universidade do Minho, Campus de Gualtar, 4710-057 Braga, Portugal

* Submitted: 15-10-2016

* Accepted: 21-01-2017 